\title{
Tingkat Kepuasan Pasien Terhadap Pelayanan Kefarmasian di Apotek Kabupaten Rembang
}

\section{Patients' Satisfaction with Pharmaceutical Care in Community Pharmacies in The District of Rembang}

\author{
Sally Astya Utami, Zakky Cholisoh* \\ Fakultas Farmasi, Universitas Muhammadiyah Surakarta, \\ J1 A Yani Tromol Pos 1, Pabelan Kartasura Surakarta 57102 Telp. (0271)717417 \\ *Email: zakky.cholisoh@ums.ac.id
}

\begin{abstract}
Abstrak
Peraturan pemerintah mengatur standar pelayanan kefarmasian di apotek untuk menjamin mutu pelayanan yang berorientasi kepada pasien. Dampak tidak dilaksanakannya kegiatan pelayanan kefarmasian yang baik adalah dapat terjadi kesalahan pengobatan (medication error) dalam proses pelayanan kefarmasian. Penelitian bertujuan untuk mengetahui ada atau tidaknya korelasi antara kepuasan konsumen dengan diterapkannya standar pelayanan kefarmasian apotek di Kabupaten Rembang Kota Rembang. Penelitian dikategorikan dalam penelitian cross sectional survey dengan teknik pengambilan sampel penelitian purposive sampling. Data diperoleh dengan cara membagikan kuesioner yang diisi oleh apoteker dan pasien sebagai konsumen apotek. Penelitian dilakukan pada 4 (empat) apotek di Kabupaten Rembang. Data dianalisis dengan menggunakan pearson correlation. Hasil penelitian kuesioner yang diisi 4 apoteker meliputi aspek sarana dan prasarana serta pelayanan. Pengukuran kepuasan 94 konsumen apotek digunakan 5 dimensi yaitu reliability, assurance, tangibles, empathy dan responsiveness. Tidak ada hubungan antara kualitas pelayanan kefarmasian yang dilakukan apoteker dengan kepuasan konsumen apotek p ( $95 \% ; 2$ tailed ) =0,503.
\end{abstract}

Kata kunci: standar pelayanan kefarmasian, apotek, dan apoteker.

\begin{abstract}
Government regulations regulate pharmaceutical care standards at pharmacies to ensure the quality of pharmaceutical care to patient. The impact of not implementing a good pharmaceutical service activity is that medication errors can occur in the pharmaceutical service process. The study aimed to determine if there is any correlation between customer satisfaction and the application of the standards of pharmaceutical care in Rembang. This is a cross sectional survey research with purposive sampling technique. Data was obtained by distributing questionnaires filled by community pharmacists and patients attending community pharmacies. The study was conducted at 4 (four) community pharmacies in Rembang. Data were analyzed using Pearson correlation. Questionnaires were filled by 4 pharmacists' measuring aspects of facilities, infrastructure and services. The level of satisfaction of 94 community pharmacies' patients were measured in 5 dimensions i.e. reliability, assurance, tangibles, empathy and responsiveness. The quality of pharmaceutical care scoring and patients' satisfaction showed no relationship $p(95 \% ; 2$ tailed $)=0.503$.

Keyword: standard of pharmaceutical services, drugstore, and pharmacists.
\end{abstract}

\section{PENDAHULUAN}

Tuntutan konsumen akan mutu pelayanan kefarmasian mengharuskan adanya perubahan pelayanan yang berorientasi pada produk obat, menjadi pelayanan yang berorientasi pada konsumen (Surahman \& Husen, 2011). Hal ini ditujukan untuk meningkatkan outcome terapi dan meminimalkan risiko terjadinya efek samping karena obat, untuk tujuan keselamatan pasien (patient safety) sehingga kualitas hidup pasien (quality of life). Dampak dari tidak dilaksanakannya kegiatan pelayanan kefarmasian yang baik adalah dapat terjadi kesalahan pengobatan (medication error) dalam proses pelayanan (Depkes RI, 2014). 
Pelaksanaan standar pelayanan kefarmasian yang baik akan meningkatkan kepuasan konsumen. Menurut Traverso et al., 2007 kepuasan konsumen dapat berfungsi sebagai indikator terhadap kualitas pelayanan dan sebagai prediktor terhadap perilaku konsumen yang berhubungan dengan kesehatan.

Penting menilai kepuasan kosumen terhadap pelayanan kefarmasian apotek untuk mempelajari respon konsumen terhadap mutu pelayanan yang akan diterima konsumen, untuk mengetahui kebutuhan serta harapan konsumen terhadap pelayanan, meningkatkan mutu pelayanan, merangkai susunan kerja untuk menyempurnakan kualitas pelayanan dimasa mendatang bagi pelayanan kefarmasian (Kotler et al., 2002).

Hubungan tingkat kepuasan konsumen dengan standar pelayanan kefarmasian apotek dapat diukur dengan cara mengukur tingkat kepuasan konsumen dan mengukur standar pelayanan kefarmasian apotek yang diberikan oleh apoteker berdasarkan Peraturan Menteri Kesehatan Republik Indonesia Nomor 35 Tahun 2014. Manfaat penelitian ini diharapkan dapat mengetahui ada atau tidaknya korelasi antara kepuasan konsumen apotek dengan standar pelayanan kefarmasian berdasarkan Peraturan Menteri Kesehatan Republik Indonesia Nomor 35 Tahun 2014.

\section{METODOLOGI PENELITIAN}

Penelitian yang dilakukan dikategorikan dalam penelitian non-eksperimental. Rancangan penelitian yang digunakan adalah metode survei yang bertujuan untuk menetapkan korelasi antara kepuasan konsumen apotek dengan standar pelayanan kefarmasian yang dilakukan oleh apoteker di apotek di Kabupaten Rembang Kota Rembang berdasarkan Peraturan Menteri Kesehatan Republik Indonesia Nomor 35 Tahun 2014. Kriteria inklusi konsumen apotek di Kabupaten Rembang antara lain merupakan konsumen apotek, bersedia menjadi sampel penelitian, dapat membaca dan menulis, serta berusia 15-70 tahun.

\section{Instrumen penelitian}

Alat yang digunakan untuk mengambil data adalah kuesioner. Penelitian menggunakan 2 macam kuesioner, yaitu kuesioner yang diisi oleh konsumen dan kuesioner yang diisi oleh apoteker di apotek. Pertanyaan berisi tentang harapan konsumen terhadap pelayanan kefarmasian di apotek. Tingkat kepuasan konsumen dapat diukur dari 5 dimensi, yaitu Reliability (kehandalan), Assurance (jaminan atau kepastian), Tangibles (bukti fisik/ fasilitas), Empathy (empati), Responsiveness (ketanggapan). Pertanyaan tentang standar pelayanan kefarmasian berdasarkan Peraturan Menteri Kesehatan Republik Indonesia Nomor 35 Tahun 2014 dengan beberapa parameter yaitu sarana dan prasarana, serta pelayanan farmasi klinik di apotek (Depkes RI, 2014). Instrumen penelitian telah diuji validitas dan reliabilitasnya pada 30 responden. Kuesioner untuk pasien terbukti valid ( $\mathrm{r}$ hitung $>\mathrm{r}$ tabel 0,361) dan reliabel (Cronbach's alpha 0,937). Kuesioner untuk apoteker juga dinyatakan valid ( $\mathrm{r}$ hitung $>\mathrm{r}$ tabel 0,878 ) dan reliabel (Cronbach's alpha 0,996 > 0,878).

\section{Tempat Penelitian}

Tempat penelitian dilakukan di Kabupaten Rembang Kota Rembang. Penelitian dilakukan pada 4 Kecamatan di Kabupaten Rembang yaitu Kecamatan Sulang, Kecamatan Sale, Kecamatan Pamotan, Kecamatan Kragan, masing-masing kecamatan diwakili oleh 1 ( satu) apotek.

\section{HASIL DAN PEMBAHASAN}

Response rate untuk responden apoteker adalah $100 \%$ artinya semua (4 orang) apoteker bersedia untuk menjadi responden dalam penelitian ini. Apoteker juga memberikan izin peneliti untuk membagikan kuesioner kepada konsumen apotek.

Data apotek yang diteliti meliputi nama apotek, alamat apotek, jumlah pegawai, jumlah resep lembar perhari serta jenis kepemilikan apotek. Penelitian dilakukan di 4 
Tabel 1. Nama apotek, alamat apotek, jumlah pegawai, jumlah resep, dan jenis kepemilikan

\begin{tabular}{clccl}
\hline $\begin{array}{c}\text { Nama } \\
\text { Apotek }\end{array}$ & $\begin{array}{c}\text { Alamat } \\
\text { Apotek }\end{array}$ & $\begin{array}{c}\text { Jumlah } \\
\text { Pegawai }\end{array}$ & $\begin{array}{c}\text { Jumlah Resep } \\
\text { (lembar/hari) }\end{array}$ & Jenis kepemilikan \\
\hline $\begin{array}{l}\text { Apotek } \\
\text { Husada } \\
\text { Apotek }\end{array}$ & $\begin{array}{l}\text { Kecamatan } \\
\text { Sale }\end{array}$ & 5 & 4 & Apotek sendiri \\
Kecamatan & 6 & $2-3$ & $\begin{array}{l}\text { Perorangan (Pemilik } \\
\text { Surana Apotek) }\end{array}$ \\
$\begin{array}{l}\text { Apotek } \\
\text { Tazzaka }\end{array}$ & $\begin{array}{l}\text { Kecamatan } \\
\text { Pamotan }\end{array}$ & 5 & 3 & $\begin{array}{l}\text { Perorangan (Pemilik } \\
\text { Sarana Apotek) }\end{array}$ \\
$\begin{array}{l}\text { Apotek } \\
\text { Kragan }\end{array}$ & $\begin{array}{l}\text { Kecamatan } \\
\text { Kragan }\end{array}$ & 4 & $2-3$ & $\begin{array}{l}\text { Perorangan (Pemilik } \\
\text { Sarana Apotek) }\end{array}$ \\
\hline
\end{tabular}

apotek Kecamatan Rembang Kabupaten Rembang dengan peta yang terdapat pada lampiran.

Tabel 1 menunjukkan di antara apotek yang diteliti Apotek Sulang memiliki jumlah pegawai paling banyak yaitu 6 pegawai. Apotek Husada memiliki jumlah resep paling banyak yaitu 4 lembar/hari. Tujuh puluh lima persen apotek jenis kepemilikannya yaitu perorangan (pemilik sarana apotek).

Data apoteker yang diteliti meliputi nama apoteker, jenis kelamin, usia, jabatan apoteker, pekerjaan lain (sampingan) apoteker, frekuensi kehadiran dan durasi kehadiran apoteker di apotek.

Usia 4 apoteker apotek di Kabupaten Rembang termasuk dalam kategori dewasa awal dengan rentang usia 26-35 tahun (Depkes, 1990). Jabatan apoteker apotek yang diteliti semuanya sebagai apoteker penanggung jawab. Hasil kuesioner menyatakan 1 apoteker yang diteliti mempunyai pekerjaan lain yaitu Apotek Husada. Sedangkan 3 apoteker lainnya menyatakan tidak ada pekerjaan lain (sampingan).
Frekuensi kehadiran apoteker Apotek Husada hanya 2 kali dalam satu bulan. Frekuensi kehadiran apoteker Apotek Husada berlawanan Peraturan Menteri Kesehatan Republik Indonesia Nomor 35 Tahun 2014 yang menyatakan jika apotek melakukan pelayanan kefarmasian maka apoteker harus mudah ditemui. Dilihat dari lama durasi apoteker berada di apotek, maka apoteker Apotek Husada dan Apotek Sulang lebih lama yaitu 8 jam/hari.

Sumber daya kefarmasian menurut Peraturan Menteri Kesehatan Republik Indonesia Nomor 35 Tahun 2014 meliputi sumber daya manusia serta sarana dan prasarana. Sumber daya manusia yang dimaksudkan dalam peraturan adalah apoteker yang melakukan pelayanan kefarmasian dan dapat dibantu oleh apoteker pendamping.

Detail sarana dan prasarana apotek yang diteliti di Kabupaten Rembang dapat dilihat pada tabel 3. Sebanyak $100 \%$ apotek mempunyai papan nama apotek, ruang tunggu, tempat mendisplai informasi obat, ruang racikan, Standard Operating Procedure

Tabel 2. Data demografi apoteker di 4 apotek di Kabupaten Rembang Kota Rembang

\begin{tabular}{lcccc}
\hline \multicolumn{1}{c}{ Apoteker } & $\begin{array}{c}\text { Jenis } \\
\text { kelamin }\end{array}$ & $\begin{array}{c}\text { Usia } \\
\text { (Tahun) }\end{array}$ & $\begin{array}{c}\text { Frekuensi kehadiran } \\
\text { (perbulan) }\end{array}$ & $\begin{array}{c}\text { Durasi kehadiran } \\
\text { (jam) }\end{array}$ \\
\hline Apotek Husada & Pria & 34 & 2 & 8 \\
Apotek Sulang & Pria & 27 & 20 & 8 \\
Apotek Tazzaka & Wanita & 32 & 24 & 6 \\
Apotek Kragan & Wanita & 34 & 16 & 7 \\
\hline
\end{tabular}


Tabel 3. Distribusi penelitian sarana dan prasarana apotek di Kabupaten Rembang Kota Rembang

\begin{tabular}{lcc}
\hline \multicolumn{1}{c}{ Sarana dan prasarana di apotek } & Jumlah Apotek & $\begin{array}{c}\text { Persentase } \\
(\%)\end{array}$ \\
\hline Papan nama apotek & 4 & $100 \%$ \\
Ruang tunggu apotek & 4 & $100 \%$ \\
Tempat untuk mendisplai informasi bagi pasien atau tempat & 4 & $100 \%$ \\
$\quad$ brosur/ leaflet /buletin & & $75 \%$ \\
Ruang konseling & 3 & $100 \%$ \\
Ruang racikan & 4 & $100 \%$ \\
$\quad \begin{array}{l}\text { Tersedia Standard Operating Procedure tertulis terkait } \\
\quad \text { pemeriksaan resep }\end{array}$ & 4 & $100 \%$ \\
$\quad \begin{array}{l}\text { Tersedia Standard Operating Procedure tertulis terkait } \\
\quad \text { dispensing }\end{array}$ & 4 & $100 \%$ \\
Tempat sampah & & \\
\hline
\end{tabular}

tertulis terkait pemeriksaan resep dan dispensing. Sarana dan prasarana yang harus dipunyai oleh apotek menurut Peraturan Menteri Kesehatan Republik Indonesia Nomor 35 Tahun 2014 adalah ruang menerima resep, ruang pelayanan resep dan peracikan, ruang penyerahan obat, ruang konseling, ruang penyimpanan dan ruang pengarsipan. Peraturan Menteri Kesehatan Republik Indonesia Nomor 35 Tahun 2014 tidak mempersyaratkan ruang tunggu dan tempat mendisplai informasi obat untuk menunjang pelayanan kefarmasian di apotek. Walau tidak dipersyaratkan ruang tunggu tetap dibutuhkan agar pengunjung apotek lebih nyaman dalam menunggu pelayanan di apotek tersebut. Tempat mendisplai informasi obat juga dibutuhkan untuk menambah wawasan pengunjung apotek tentang obatobatan maupun informasi tentang kesehatan lainnya.

Pada tabel 3 hanya $75 \%$ apotek yang memiliki ruang konseling. Ruang konseling dibutuhkan untuk melakukan kegiatan komunikasi yang dilakukan oleh apoteker dengan konsumen atau keluarga dari konsumen. Konseling obat oleh apoteker bertujuan untuk meningkatkan pengetahuan dan kepatuhan pasien dalam penggunaan obat (Depkes RI, 2014)

Tabel 4 menunjukkan apoteker Apotek Husada menyatakan dari beberapa item persyaratan pelayanan kefarmasian yang ditanyakan dalam kuesioner, apoteker hanya melakukan konseling. Isi konseling yang diberikan oleh apoteker Apotek Husada meliputi informasi aturan pakai obat dan cara penggunaan obat. Apoteker Apotek Tazzaka menyatakan hanya melakukan pengkajian resep. Isi pertanyaan pengkajian resep yang dilakukan meliputi ketepatan indikasi, dosis obat dan duplikasi obat.

Apoteker Apotek Kragan menyatakan dari beberapa item persyaratan pelayanan kefarmasian yang ditanyakan dalam

Tabel 4. Apoteker yang menyatakan selalu melakukan item persyaratan pelayanan kefarmasian berdasarkan Peraturan Menteri Kesehatan Republik Indonesia Nomor 35 Tahun 2014

\begin{tabular}{lcccc}
\hline \multicolumn{1}{c}{ Kegiatan } & $\begin{array}{c}\text { Apoteker } \\
\text { Apotek } \\
\text { Husada }\end{array}$ & $\begin{array}{c}\text { Apoteker } \\
\text { Apotek } \\
\text { Sulang }\end{array}$ & $\begin{array}{c}\text { Apoteker } \\
\text { Apotek } \\
\text { Tazzaka }\end{array}$ & $\begin{array}{c}\text { Apoteker } \\
\text { Apotek } \\
\text { Kragan }\end{array}$ \\
\hline Pengkajian Resep & - & $\sqrt{ }$ & $\sqrt{ }$ & $\sqrt{ }$ \\
Dispensing & - & $\sqrt{ }$ & - & $\sqrt{ }$ \\
Pelayanan Informasi Obat (PIO) & - & - & - & $\sqrt{ }$ \\
Konseling & $\sqrt{ }$ & $\sqrt{ }$ & - & - \\
Home Pharmacy Care & - & - & - & - \\
Pemantauan Terapi Obat & - & $\sqrt{ }$ & - & - \\
Monitoring Efek Samping Obat (MESO) & - & $\sqrt{ }$ & - & - \\
\hline
\end{tabular}


Tabel 6. Karakteristik konsumen apotek di Kabupaten Rembang $(n=94)$

\begin{tabular}{|c|c|c|c|c|c|}
\hline $\begin{array}{c}\text { Karakteristik } \\
\text { Konsumen } \\
\end{array}$ & $\begin{array}{l}\text { Apotek } \\
\text { Husada }\end{array}$ & $\begin{array}{l}\text { Apotek } \\
\text { Sulang }\end{array}$ & $\begin{array}{c}\text { Apotek } \\
\text { Tazzaka } \\
\end{array}$ & $\begin{array}{l}\text { Apotek } \\
\text { Kragan }\end{array}$ & Total \\
\hline \multicolumn{6}{|l|}{ Usia : } \\
\hline$-15-45$ & $20(90,90 \%)$ & $17(80,95 \%)$ & $16(69,56 \%)$ & $27(96,42 \%)$ & $80(85.10 \%)$ \\
\hline$-46-70$ & $2(9,10 \%)$ & $4 \quad(19,05 \%)$ & $7(30,44 \%)$ & $1 \quad(3,58 \%)$ & $14(14,9 \%)$ \\
\hline \multicolumn{6}{|l|}{ Jenis Kelamin : } \\
\hline - Pria & $10(45,45 \%)$ & $10(47,61 \%)$ & $4 \quad(17,39 \%)$ & $19(67,85 \%)$ & $43(45,74 \%)$ \\
\hline - Wanita & $12(54,55 \%)$ & $11(52,39 \%)$ & $19(82,61 \%)$ & $9(32,15 \%)$ & $51(54,26 \%)$ \\
\hline \multicolumn{6}{|l|}{ Pendidikan : } \\
\hline -Tidak tamat SD & $0 \quad(0 \%)$ & $0 \quad(0 \%)$ & $2(9,09 \%)$ & $1 \quad(3,57 \%)$ & $3(3,19 \%)$ \\
\hline$-\mathrm{SD}$ & $2(9,09 \%)$ & $3(14,28 \%)$ & $4(18,18 \%)$ & $2(7,14 \%)$ & $11(11,70 \%)$ \\
\hline -SMP & $5 \quad(22,72 \%)$ & $3(14,28 \%)$ & $7 \quad(31,81 \%)$ & $4(14,28 \%)$ & $19(20,21 \%)$ \\
\hline -SMA & $12(54,54 \%)$ & $12(57,16 \%)$ & $7 \quad(27,27 \%)$ & $13(46,42 \%)$ & $44(46,80 \%)$ \\
\hline -Perguruan tinggi & $3(13,65 \%)$ & $3(14,28 \%)$ & $3(13,65 \%)$ & $8 \quad(28,59 \%)$ & $17(18,10 \%)$ \\
\hline \multicolumn{6}{|l|}{ Pekerjaan : } \\
\hline - Pelajar & $0 \quad(0 \%)$ & $1 \quad(4,76 \%)$ & $0 \quad(0 \%)$ & $4 \quad(14,28 \%)$ & $5 \quad(5,31 \%)$ \\
\hline - Mahasiswa & $1 \quad(4,54 \%)$ & $0 \quad(0 \%)$ & $0 \quad(0 \%)$ & $2(7,14 \%)$ & $3(3,19 \%)$ \\
\hline - Wiraswasta & $6 \quad(27,27 \%)$ & $7 \quad(33,33 \%)$ & $5 \quad(21,73 \%)$ & $8 \quad(28,57 \%)$ & $26(27,65 \%)$ \\
\hline - PNS & $0 \quad(0 \%)$ & $0 \quad(0 \%)$ & $1 \quad(4,34 \%)$ & $3(10,71 \%)$ & $4 \quad(4,25 \%)$ \\
\hline - Pegawai & $5 \quad(22,72 \%)$ & $3(14,28 \%)$ & $1 \quad(4,34 \%)$ & $4 \quad(14,28 \%)$ & $13(13,82 \%)$ \\
\hline swasta & $7 \quad(31,81 \%)$ & $8 \quad(38,09 \%)$ & $13(56,52 \%)$ & $5(17,88 \%)$ & $33(35,10 \%)$ \\
\hline $\begin{array}{l}\text { - Ibu rumah } \\
\text { tangga } \\
\text { - Lain-lain }\end{array}$ & $3(13,66 \%)$ & $2(9,54 \%)$ & $3(13,34 \%)$ & $2(7,14 \%)$ & $10(10,68 \%)$ \\
\hline \multicolumn{6}{|l|}{$\begin{array}{l}\text { Kunjungan } \\
\text { apotek sebulan } \\
\text { terakhir: } \\
\text { - Pertama kali }\end{array}$} \\
\hline $\begin{array}{l}\text { - Pertama kali } \\
\text { - 2-5 kali }\end{array}$ & $4(18,18 \%)$ & $3(14,28 \%)$ & $0 \quad(0 \%)$ & $2(7,14 \%)$ & $9 \quad(9,57 \%)$ \\
\hline - Lebih dari 5 & $7(31,81 \%)$ & $5 \quad(23,80 \%)$ & $5 \quad(21,73 \%)$ & $7 \quad(25,00 \%)$ & $24(25,53 \%)$ \\
\hline kali & $11(50,01 \%)$ & $13(61,92 \%)$ & $18(78,27 \%)$ & $19(67,86 \%)$ & $61(64,90 \%)$ \\
\hline \multicolumn{6}{|l|}{ Obat yang } \\
\hline $\begin{array}{l}\text { - Obat resep } \\
\text { - Obat bukan } \\
\text { resep }\end{array}$ & $18(81,82 \%)$ & $20(95,24 \%)$ & $21(91,31 \%)$ & $25(89,29 \%)$ & $84(89,37 \%)$ \\
\hline \multicolumn{6}{|l|}{ Obat untuk : } \\
\hline - Diri sendiri & $7 \quad(31,81 \%)$ & $12(57,14 \%)$ & $10(43,47 \%)$ & $11(39,28 \%)$ & $40(42,55 \%)$ \\
\hline - Keluarga & $14(63,63 \%)$ & $9 \quad(42,86 \%)$ & $11(47,82 \%)$ & $17(60,72 \%)$ & $51(54,25 \%)$ \\
\hline - Orang lain & $1 \quad(4,56 \%)$ & $0 \quad(0 \%)$ & $2(8,71 \%)$ & $0 \quad(0 \%)$ & $3(3,20 \%)$ \\
\hline
\end{tabular}

kuesioner, apoteker melakukan 4 item persyaratan pelayanan kefarmasian yaitu pengkajian resep, dispensing, pelayanan informasi obat, dan konseling. Isi pengkajian resep yang dilakukan meliputi penyiapan obat sesuai dengan resep, pengkajian administrasi (umur pasien, jenis kelamin pasien, nama dokter, alamat dokter, nomor telepon dokter, dan tanggal penulisan resep), pengkajian pertimbangan klinis (ketepatan indikasi, dosis obat, duplikasi obat, efek samping obat, kontraindikasi obat dan interaksi obat). Sedangkan item pertanyaan dispensing yang dilakukan meliputi pemeriksaan kualitas fisik obat dan tanggal kadaluwarsa obat. Isi pertanyaan pelayanan informasi obat yang diberikan apoteker hanya membantu menyelesaikan masalah penggunaan obat kepada konsumen. Isi konseling yang diberikan oleh apoteker Apotek Kragan meliputi informasi indikasi obat, dosis obat, aturan pakai obat, cara penggunaan obat, kontraindikasi obat, efek samping obat, dan penyimpanan obat.

Apoteker Apotek Sulang merupakan Apoteker yang paling banyak melakukan item persyaratan pelayanan kefarmasian. Pelayanan kefarmasian yang dilakukan adalah pengkajian resep, dispensing, konseling, pemantauan terapi obat, dan 
monitoring efek samping obat. Isi pertanyaan pengkajian resep yang dilakukan oleh apoteker Apotek Sulang meliputi penyiapan obat sesuai dengan resep, pengkajian administrasi (nama pasien, umur pasien, jenis kelamin pasien, berat badan pasien, nama dokter, nomor SIP dokter, alamat dokter, nomor telepon dokter, paraf dokter dan tanggal penulisan resep), dan melakukan pengkajian kesesuaian farmasetik yaitu bentuk sedian. Isi pertanyaan dispensing yang dilakukan yaitu pemeriksaan tanggal kadaluwarsa obat. Isi konseling yang diberikan meliputi informasi indikasi obat, dosis obat, aturan pakai obat, cara penggunaan obat, kontraindikasi obat, efek samping obat, dan penyimpanan obat, serta apoteker melakukan pemantauan terapi obat sesuai dengan kondisi konsumen dan memantau pasien yang beresiko mengalami efek samping obat.

Masih banyak kegiatan pelayanan kefarmasian yang dipersyaratkan oleh Peraturan Menteri Kesehatan Republik Indonesia Nomor 35 Tahun 2014 yang belum dilakukan di 4 apotek. Hal ini dapat mengakibatkan medication error dalam proses pelayanan kefarmasian (Depkes RI, 2014).

Tabel 6. Jumlah konsumen yang bersedia mengisi kuesioner

\begin{tabular}{lc}
\hline \multicolumn{1}{c}{ Apotek } & $\begin{array}{c}\text { Jumlah } \\
\text { Responden }\end{array}$ \\
\hline Apotek Husada & 23 \\
Apotek Sulang & 22 \\
Apotek Tazzaka & 21 \\
Apotek Kragan & 28 \\
\hline
\end{tabular}

Berdasarkan rumus perhitungan sampel, peneliti seharusnya mengambil 96 responden, akan tetapi hanya 94 responden apotek yang bersedia mengisi kuesioner konsumen apotek, maka response rate responden apotek adalah $97,92 \%$.

Teknik pengambilan sampel penelitian dengan cara purposive sampling yaitu pengambilan sampel dengan dasar pertimbangan tertentu yang dibuat oleh peneliti sendiri.

Data karakteristik pengunjung apotek (tabel 6) menunjukkan bahwa sebesar 85,10 $\%$ berusia 15-45 tahun. Jenis kelamin pengunjung apotek sebagian besar adalah wanita $(54,26 \%)$. Tingkat pendidikan konsumen yang paling tinggi adalah SMA dengan persentase $46,80 \%$. Pekerjaan konsumen apotek rata-rata adalah ibu rumah tangga 35,10\%. Sebanyak 64,90\% konsumen mengunjungi apotek lebih dari 5 kali dalam sebulan terakhir. Konsumen sebagian besar membeli OTC (over the counter medicines) $(89,37 \%)$, hal ini mungkin disebabkan lokasi apotek jauh dari tempat praktik dokter, sehingga jumlah konsumen yang menebus resep hanya $10,63 \%$. Obat yang dibeli oleh konsumen apotek sebagian besar untuk keluarga $(54,25 \%)$.

Uji normalitas dimensi kehandalan, ketanggapan, keyakinan, empati, dan fasilitas hasilnya tidak terdistribusi normal, maka digunakan uji Kruskal Wallis untuk membandingkan data kepuasan konsumen di 4 apotek Kabupaten Rembang. Uji Kruskal Wallis pada dimensi kehandalan didapatkan nilai p-value sebesar $0,836>$ nilai kritik 0,05 , maka tidak terdapat cukup bukti untuk membuktikan dari 4 apotek dalam menilai dimensi kehandalan mana yang paling baik. Artinya walaupun pada gambar 1 dimensi kehandalan Apotek Kragan menunjukkan rata-rata skor paling tinggi, namun pada uji Kruskal Wallis dimensi kehandalan Apotek Kragan tidak dapat dikatakan paling tinggi. Uji Kruskal Wallis dimensi ketanggapan didapatkan nilai p-value sebesar 0,072 > nilai kritik 0,05 , maka tidak terdapat cukup bukti untuk membuktikan dari 4 apotek dalam menilai dimensi ketanggapan.

Uji Kruskal Wallis dimensi keyakinan didapatkan nilai p-value sebesar 0,139 > nilai kritik 0,05, maka tidak terdapat cukup bukti untuk membuktikan dari ke 4 apotek dalam menilai dimensi keyakinan. Uji Kruskal Wallis dimensi empati didapatkan nilai $\mathrm{p}$ - 


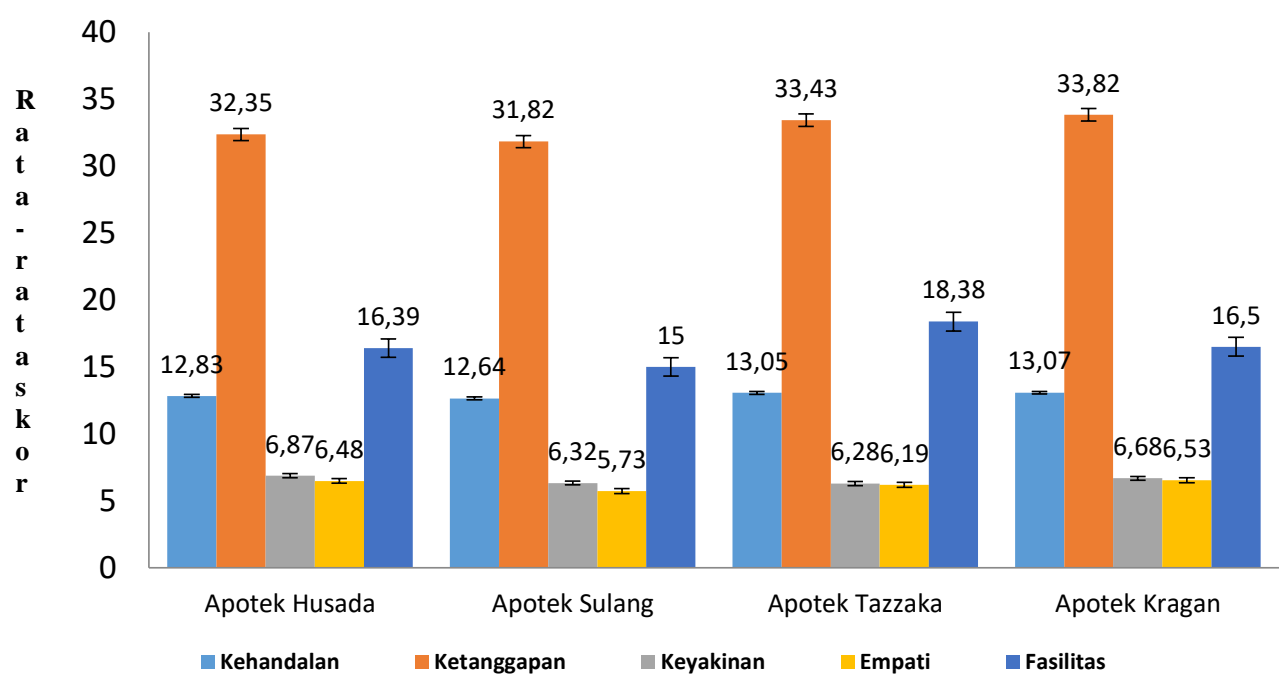

Gambar 1. Rata-rata skor kepuasan konsumen di 4 apotek di Kabupaten Rembang.

value sebesar $0,049<$ nilai kritik 0,05, maka terdapat cukup bukti dimana terdapat perbedaan untuk membuktikan dari ke 4 apotek dalam menilai dimensi empati. Artinya rata-rata skor kepuasan konsumen Apotek Kragan terhadap dimensi empati lebih besar dibandingkan dengan Apotek Husada, Sulang dan Tazzaka. Uji Kruskal Wallis dimensi fasilitas didapatkan nilai pvalue sebesar $0,031<$ nilai kritik 0,05 , maka terdapat cukup bukti dimana terdapat perbedaan untuk membuktikan dari ke 4 apotek dalam menilai dimensi fasilitas. Artinya gambar 1 menunjukkan tingkat kepuasan konsumen Apotek Tazzaka terhadap dimensi fasilitas lebih besar dibandingkan dengan Apotek Husada, Sulang, dan Kragan.

Uji normalitas berfungsi untuk mengetahui data-data yang diperoleh terdistribusi normal atau tidak terdistribusi normal. Dasar pengambilan keputusan dapat dilihat dari nilai signifikasi atau nilai probabilitas data < 0,05, maka data dinyatakan tidak terdistribusi normal. Jika nilai signifikasi atau nilai probabilitas data > 0,05, maka data dinyatakan terdistribusi normal (Widiyanto, 2014).

Pelayanan kefarmasian yang diuji menggunakan uji Shapiro-Wilk didapatkan nilai signifikasi atau nilai probabilitas sebesar
$0,618>0,05$ maka data pelayanan kefarmasian dengan uji Shapiro-Wilk dinyatakan terdistribusi normal. Kepuasan konsumen yang diuji menggunakan uji Shapiro-Wilk, nilai signifikasi atau nilai probabilitas didapatkan 0,05 , hasil tersebut seimbang yaitu tidak kurang dari 0,05 maka hasil dinyatakan terdistribusi normal.

Standar pelayanan kefarmasian menurut Peraturan Menteri Kesehatan Republik Indoneisa Nomor 35 Tahun 2014 dalam penelitian terhadap kuesioner apoteker meliputi pengkajian resep, dispensing, pelayanan informasi obat, konseling, home pharmacy care, pemantauan terapi obat, dan monitoring efek samping obat. Pengukuran kepuasan konsumen apotek digunakan 5 dimensi kepuasan yaitu reliability (kehandalan), assurance (jaminan atau kepastian), tangibles (bukti fisik/ fasilitas), empathy (empati) dan responsiveness (ketanggapan) (Parasuraman, 1988). Analisis data untuk mengetahui ada atau tidaknya korelasi antara pelayanan kefarmasian dengan kepuasan konsumen digunakan pearson correlation. Dari rata-rata skor pelayanan kefarmasian yang dilakukan oleh apoteker dan rata-rata skor kepuasan konsumen apotek menunjukkan tidak ada hubungan antara pelayanan kefarmasian yang dilakukan apoteker dengan kepuasan 
konsumen apotek yang dibuktikan dengan $\mathrm{p}$ $(95 \% ; 2$ tailed $)=0,503$.

\section{KESIMPULAN}

Hasil skor pelayanan kefarmasian yang dilakukan apoteker dengan kepuasan konsumen apotek di Kabupaten Rembang Kota Rembang menunjukkan nilai p ( $95 \%$; 2 tailed ) $=0,503>0,05$, artinya tidak ada korelasi atau hubungan antara kepuasan konsumen dengan pelayanan kefarmasian yang dilakukan apoteker apotek di Kabupaten Rembang Kota Rembang.

\section{SARAN}

Penelitian ini telah dilakukan dengan perhitungan jumlah sampel yang representative, tetapi masih belum bisa menunjukkan hubungan antara dilakukannya standar pelayanan kefarmasian di apotek dengan kepuasan pasien. Penelitian lanjutan dengan jumlah sampel yang lebih besar diperlukan agar penelitian ini dapat digeneralisasi dengan baik.

Kegiatan pelayanan kefarmasian harus ditingkatkan dengan cara memperbaiki pelayanan kefarmasian yang kurang atau belum dilaksanakan. Meningkatkan pelayanan kefarmasian dapat dilakukan dengan cara menambah wawasan atau ilmu pengetahuan, meningkatkan ketrampilan serta berperilaku yang baik, sehingga pelayanan kefarmasian yang diberikan apoteker kepada konsumen apotek atau masyarakat sesuai dengan Peraturan Menteri Kesehatan Republik Indonesia Nomor 35 Tahun 2014, yang bertujuan untuk meningkatkan kualitas hidup dan keselamatan masyarakat (Depkes RI, 2014).

\section{Daftar Pustaka}

Depkes, 2014. Peraturan Menteri Kesehatan Republik Indonesia Nomor 35 Tahun 2014. Standar Pelayanan Kefarmasian Di Apotek.

Kotler, Philip., 2002. Manajemen Pemasaran: Analisis Perencanaan, Implementasi Dan Kontrol Edisi Milenium. Jakarta: PT. Prehalindo.

Surahman, E.M. \& Husen, I.R., 2011. Konsep Dasar Pelayanan Kefarmasian Berbasiskan Pharmaceutical Care F. K.-U. Padjajdjaran, ed., Bandung: Widya Padjadjaran.

Traverso, A.L.U.Z. et al., 2007. Questionnaire to assess patient satisfaction with pharmaceutical care in Spanish language. Internasional Journal for Quality in Health Care, 19(4), pp.217-224.

Widiyanto, Joko., 2014. SPSS For Windows Untuk Analisis Data Statistik dan Penelitian, Surakarta: BP-FKIP UMS. 